\title{
ORAL HEALTH CHANGES DURING EARLY PHASE OF ORTHODONTIC TREATMENT
}

\author{
Karlo Sudarević ${ }^{1}$, Antonija Jurela ${ }^{1}$, Dario Repić ${ }^{2}$ Dražen Jokić ${ }^{3}$, Ivana Medvedec Mikić \\ and Slavica Pejda ${ }^{2}$
}

${ }^{1}$ Private Dental Practice, Zagreb; ${ }^{2}$ School of Medicine, University of Split, Split; ${ }^{3}$ Department of Oral and Maxillofacial Surgery, Dubrava University Hospital, Zagreb, Croatia

\begin{abstract}
SUMMARY - The aim of the study was to assess the influence of fixed orthodontic appliance on Streptococcus (S.) mutans and S. sobrinus counts in orthodontic patients with regard to their previous caries experience (Decayed, Missing and Filled Teeth (DMFT) index) during the first 12 weeks of orthodontic treatment. Twenty-two patients that satisfied inclusion criteria (healthy systemic and periodontal condition, avoidance of antibiotic therapy and antiseptic mouthwashes in the past three months) were included. All clinical measurements took place prior to and 12 weeks after fixed orthodontic appliance placement, in the following order: 1) stimulated saliva flow (SS); 2) Simplified Oral Hygiene Index (OHI-S); and 3) DMFT. The method of polymerase chain reaction (PCR) was used to detect the presence of $S$. mutans and S. sobrinus at T1 and T2. T-test showed significant increase in DMFT index and SS between T1 and T2. Results also indicated significant improvement in OHI-S index. By use of the PCR method, S. mutans was detected in two patients at T1. At T2, two more patients had $S$. mutans, but the increase was not statistically significant. Using the same method, S. sobrinus was detected only in two patients at T2. In conclusion, fixed orthodontic appliances did not induce statistically significant changes in caries microflora even in the presence of enhanced oral hygiene habits.
\end{abstract}

Key words: Dental enamel; Dental caries; Decayed, Missing and Filled surface index; Streptococcus mutans; Streptococcus sobrinus; Orthodontic appliances

\section{Introduction}

Unwanted effects of fixed orthodontic appliance on oral health have been proven in numerous studies ${ }^{1,2}$. One of such is increase in plaque accumulation, which presents a risk factor for enamel demineralization and might result in discontinuation of orthodontic treatment $^{3,4}$. Prevention of enamel demineralization poses a serious problem for patients and clinicians during fixed orthodontic treatment. According to Fink and $\mathrm{Smith}^{5}$, the mean duration of orthodontic treatment was 23.1 months. As most of orthodontic patients

Correspondence to: Slavica Pejda, DMD, PhD, School of Medicine, University of Split, Šoltanska 2, HR-21000 Split, Croatia E-mail:spejda@gmail.com

Received September 25, 2013, accepted October 15, 2014 are preadolescent and adolescent ${ }^{6}$, it is unlikely to expect high levels of oral hygiene habits throughout the treatment. Although conventional caries risk parameters (Decayed, Missing and Filled Teeth (DMFT) index, plaque values, and salivary flow) are described and provide important information on patient caries risk profile, there is still controversy regarding their interrelationship ${ }^{4,7}$. Oral microbiota attachment in orthodontic patients has been mainly associated with an increased level of Streptococcus (S.) mutans and $S$. sobrinus, which have been recognized as etiological agents of dental caries ${ }^{8-10}$. However, few authors question the role of $S$. mutans and underline the role of $S$. sobrinus in caries development ${ }^{10,11}$. Despite improvements in the properties of dental materials and prophylactic efforts, enamel demineralization during 
orthodontic treatment still presents a clinical challenge. The aim of this study was to assess the influence of fixed orthodontic appliance on $S$. mutans and S. sobrinus counts in patients with regard to their previous caries experience (DMFT index) during the first 12 weeks of orthodontic treatment. Further, the objective of the present study was to identify the role of caries risk factors such as Simplified Oral Hygiene Index (OHI-S), stimulated salivary flow (SS) and their possible changes during the first 12 weeks of orthodontic treatment.

\section{Patients and Methods}

This prospective clinical study included 22 patients, twelve (54.5\%) female and ten (45.5\%) male, with fixed orthodontic appliances (Discovery, Dentaurum, Germany and Spirit MB, Ormco/A Company, Florida, USA). Blue phase G2, Ivoclar, Vivadent adhesive was used for brackets bonding and elastomere ligatures were used for ligation. Patients were recruited at a private orthodontic office in Zagreb, Croatia, and all satisfied the following inclusion criteria: healthy systemic and periodontal condition (depth of periodontal pockets $\leq 3 \mathrm{~mm}$ ) and avoidance of antibiotic therapy and antiseptic mouthwashes during and three months before the study. The study was approved by the Ethics Committee, School of Dental Medicine, University of Zagreb, Zagreb, Croatia, and all patients or their parents signed the informed consent form. All patients received precise instructions on oral hygiene regime (instructions on tooth brushing methods, especially around brackets for a minimum of 3 minutes three times a day) and exclusion of dietary intake before orthodontic appliance placement and during each recall. All clinical measurements took place in the dental chair, between 9 and $11 \mathrm{AM}$ at $\mathrm{T} 1$ (prior to placement of fixed orthodontic appliance) and T2 (12 weeks after placement of fixed orthodontic appliance) in the following order: 1) SS; 2) OHI-S index; and 3) DMFT index.

\section{Stimulated whole saliva collection}

All patients were asked to refrain from eating, drinking and tooth brushing two hours prior to all clinical examinations. Patients were asked to chew $1 \mathrm{~g}$ of paraffin wax during one minute, followed by saliva collection into calibrated, dry and sterilized test tubes during five minutes. The obtained salivary amount was expressed as $\mathrm{mL} / \mathrm{min}^{12}$.

\section{Simplified Oral Hygiene Index}

Six index teeth according to the Green and Vermilion Simplified OHI-S index ${ }^{13}$ were used to determine plaque values. The presence of orthodontic brackets on the teeth disturbs evaluation of plaque values as described in OHI-S index, therefore plaque values were determined in dichotomies (positive presence of plaque on labial surface was marked as 1 and negative as 0). Oral Hygiene Index (OHI) was calculated as total score divided by number 6 .

\section{Decayed, Missing and Filled Teeth Index}

The DMFT index includes a record of the presence or absence of all teeth including presumptive cause of tooth loss. DMFT index was determined using the sum of decayed (DT), missing (MT) and filled (FT) teeth, according to the World Health Organization ${ }^{14}$. Examinations were performed using a dental mirror, dental explorer and full-mouth set of periapical radiographs. Prior to clinical examination of DMFT, each tooth was cleaned and dried with an oil-free drier. Patients were divided into two groups according to DMFT index in T0: high caries risk group (DMFT $>11.44$ ) and low caries risk group (DMFT <11.44). We used data from the study by Uludamar et al. ${ }^{15}$ to set a DMFT value of 11.44 as the border between the high and low caries risk groups.

\section{Bacterial markers}

DNA isolation, PCR amplification and detection were performed as previously described ${ }^{16,17}$.

Complete microbiological analysis was performed at the Department of Clinical and Molecular Microbiology, Zagreb University Hospital Center, Zagreb, Croatia.

\section{Statistical analysis}

Statistical calculations were done by use of the Statistical Package for Social Sciences 19 (SPSS Inc., Chicago, IL, USA). Data were tested regarding the normality of distribution by applying the ShapiroWilks test. OHI-S at both T1 $(\mathrm{p}=0.046)$ and T2 $(\mathrm{p}=0.032)$ significantly deviated from normal distri- 
bution, therefore nonparametric tests were used. Other investigated variables had normal distribution and parametric tests were used. The results were described by the parameters of mean and standard deviation of $\mathrm{T} 1$ and T2 measurements. Differences between the two periods were analyzed with Wilcoxon test for OHI-S and paired t-test for other variables. Differences between the groups were assessed using the non standard error of the means of the variables at $\mathrm{T} 1$ and T2 are presented in Table 1 . There was nonsignificant sex difference. Paired t-test showed significant increase in DMFT index and SS between T1 and T2. Results also indicated significant improvement in OHI-S $(Z=-2.908, d f=21, p=0.004)$ (Table 2). Tests of correlation demonstrated no significant correlation between DMFT and other variables (Table 3). We

Table 1. Descriptive statistics for pretreatment (T1) and 12 weeks after treatment (T2)

\begin{tabular}{c|c|c|c|c|c|c|c|c}
\hline & \multicolumn{2}{|c|}{ Age (yrs) } & \multicolumn{2}{c|}{ DMFT } & \multicolumn{2}{c|}{ OHI-S } & \multicolumn{2}{c}{ SS (mL/min) } \\
\hline & Mean & SD & Mean & SD & Mean & SD & Mean & SD \\
\hline \multirow{2nnyyyyyy}{*}{ T1 } & \multirow{2}{*}{25.09} & \multirow{2}{*}{4.36} & 13.12 & 4.24 & 0.67 & 0.28 & 0.70 & 0.24 \\
\cline { 1 - 7 } T2 & & 13.86 & 4.09 & 0.37 & 0.30 & 0.88 & 0.37 \\
\hline
\end{tabular}

DMFT = Decayed, Missing and Filled Teeth index; OHI-S = Simplified Oral Hygiene Index; SS = stimulated saliva flow; SD = standard deviation

Table 2. Paired t-test and Wilcoxon test

\begin{tabular}{l|c|c|c}
\hline & $\mathrm{t}$ & $\mathrm{df}$ & $\mathrm{p}$ \\
\hline DMFT (T1- T2) & -4.598 & 21 & $<0.001$ \\
\hline SS (T1-T2) & -2.412 & 21 & 0.025 \\
\hline OHI-S (T1- T2) & $-2.908^{*}$ & 21 & 0.004 \\
\hline
\end{tabular}

*Wilcoxon test; DMFT = Decayed, Missing and Filled Teeth index; OHI-S = Simplified Oral Hygiene Index; SS = stimulated saliva flow; $\mathrm{T} 1=$ pretreatment; $\mathrm{T} 2=12$ weeks after treatment

paired t-test and Mann-Whitney test. For correlation between two variables we used Pearson's and Spearman's correlation coefficient. In all statistical tests, the level of significance was set at $5 \%$.

\section{Results}

The study included 22 patients, twelve (54.5\%) female and ten (45.5\%) male. The mean patient age was $25.09 \pm 4.36$, range $18-30$ years. The mean values and

Table 3. Correlation between DMFT and other variables

\begin{tabular}{l|c|c|c|c}
\hline \multicolumn{2}{c|}{} & Age & SS at T1 & OHI-S at T1 \\
\hline \multirow{3}{*}{$\begin{array}{l}\text { DMFT at } \\
\text { T1 }\end{array}$} & Pearson correlation & 0.362 & -0.031 & 0.319 \\
\cline { 2 - 5 } & Sig. (2-tailed) & 0.098 & 0.890 & $0.148^{*}$ \\
\cline { 2 - 5 } & $\mathrm{N}$ & 22 & 22 & 22 \\
\hline
\end{tabular}

*Spearman's rank correlation coefficient; DMFT = Decayed, Missing and Filled Teeth index; OHI-S = Simplified Oral Hygiene Index; SS = stimulated saliva flow; $\mathrm{T} 1$ = pretreatment; $\mathrm{T} 2$ = 12 weeks after treatment divided patients according to DMFT at T1 into low and high caries risk patients. Non paired t-test yielded no significant difference in the SS between the two groups $(\mathrm{t}=0.767, \mathrm{df}=20, \mathrm{p}=0.452$ at $\mathrm{T} 1$, and $\mathrm{t}=-0.142$, $\mathrm{df}=20, \mathrm{p}=0.888$ at $\mathrm{T} 2)$. Mann-Whitney test showed no significant difference in OHI-S index between the two groups $(Z=-1.634, p=0.173$ at $T 1$, and $Z=-0.428$, $\mathrm{p}=0.669$ at T2) either. Using PCR method, $S$. mutans was detected in two patients at T1. At T2, two more patients had $S$. mutans, but the increase was not statistically significant $(\mathrm{Z}=-1.414, \mathrm{p}=0.157)$. Using the same method, $S$. sobrinus was not detected at T1 and two cases were positive at T2. It is interesting to note that new cases of positive $S$. mutans were the same patients that had positive $S$. sobrinus at T2.

\section{Discussion}

Adverse effects of fixed orthodontic appliances present a complex problem in clinical practice even in patients who have improved their oral hygiene habits during fixed orthodontic therapy ${ }^{3,18}$.

The objective of this study was to investigate the presence of $S$. mutans and $S$. sobrinus in patients with different caries risk experience (DMFT) and to correlate the prevalence of these streptococci with plaque 
index and stimulated saliva during the first 12 weeks of orthodontic treatment.

Previous caries experience (DMFT index) is influenced by oral hygiene regime, socioeconomic issues and oral microbiological microflora, and provides crucial information to the orthodontist in treatment planning. Al Maaitah et al. ${ }^{19}$ report on a higher risk of developing enamel demineralization in patients who had at least 1 decayed and missed first molar when compared to patients who had 4 healthy permanent molars. Similarly, Al Mulla et al. ${ }^{20}$ report on the connection between a large number of decayed and filled tooth surfaces (DMFS) and higher values of $S . m u$ tans and Lactobacillus after fixed orthodontic appliance debonding, thus indicating DMFS as a possible parameter of caries risk. Although epidemiological studies carried out in many Western countries ${ }^{21,22}$ have revealed improvement in dental health, the average DMFT $(13.86 \pm 4.09)$ index in our study was found to be quite disturbing. There are several factors which should be taken into account when interpreting these data; sample size in this study was small and specific socioeconomic factors as in other transition countries combined with the lack of preventive and education programs may have influenced our findings. Data from the literature suggest the lack of research of epidemiological data regarding dental health of young adults in Croatia. The high mean value of DMFT index in this study group indicated the need of epidemiological studies and implementation of national prevention programs and education in oral hygiene habits in young adults. Results of this study indicated significant improvement in OHI-S $(Z=-2.908, d f=21$, $\mathrm{p}=0.004$ ) values at $\mathrm{T} 2$, suggesting significant oral hygiene improvement after oral hygiene instructions had been implemented before orthodontic appliance placement and at every recall. Our results are in accordance with the study by Gray and McIntyre ${ }^{23}$, who report on short-term significant reductions in plaque values when oral hygiene program was implemented during orthodontic treatment. Results from this study indicated significant increase in salivary flow rate after placement of fixed orthodontic appliances. These results are consistent with those of Chang et al. ${ }^{24}$ and Ulukapi et al. ${ }^{25}$.Isolation of cariogenic microflora has been based on laboratory procedures (colonial morphology grown, biochemical and immunologic tests), which can be inaccurate. PCR is a sensitive and specific method that uses specific DNA fractions for detection of microorganisms ${ }^{26}$. Results from this study indicated a slight, statistically nonsignificant increase in cariogenic microflora during the T1-T2 period. Using the PCR method, we were not able to detect $S$. sobrinus at T1, whereas at T2 S. sobrinus was detected in two patients. The counts of $S$. mutans also showed a statistically nonsignificant increase over the T1-T2 period. Although our results showed significant decrease in OHI-S values during the study period, this improvement was not followed by improvement in the cariogenic microflora counts. A similar finding has been reported by SmiechSlomkowska et al. ${ }^{18}$. It is interesting that new cases of positive $S$. sobrinus were found in the same patients that had positive $S$. mutans at T2. According to literature reports ${ }^{27}$, those patients can harbor significantly higher caries incidence than those with either $S$. mutans or $S$. sobrinus alone. Furthermore, Ortendahl et al. ${ }^{28}$ report on the development of enamel demineralization during orthodontic treatment only in patients with $S$. sobrinus detected in the plaque. In conclusion, the presence of fixed orthodontic appliances presents a caries risk factor. Clinicians should evaluate the patient's oral hygiene habits and motivation. Cariogenic microflora, especially in patients with high DMFT index before and during orthodontic treatment, should be assessed in order to apply individual preventive oral hygiene measures and to diminish adverse side effects of orthodontic treatment.

\section{Conclusion}

It is concluded that fixed orthodontic appliances did not induce statistically significant changes $(\mathrm{p}=0.157)$ in oral environment during the first 12 weeks of orthodontic treatment. Significant improvement of oral hygiene $(\mathrm{p}=0.004)$ was noticed during the first 12 weeks of orthodontic treatment. Adverse side effects during orthodontic treatment can be diminished with proper individual evaluation of the patient's oral hygiene habits and appropriate prevention.

\section{References}

1. JORDAN C, LeBLANC DJ. Influences of orthodontic appliances on oral populations of mutans streptococci. Oral Microbiol Immunol 2002;17:65-71. 
2. NARANJO AA, TRIVINO ML, JARAMILLO A, BETANCOURTH M, BOTERO JE. Changes in the subgingival microbiota and periodontal parameters before and 3 months after bracket placement. Am J Orthod Dentofacial Orthop 2006;130:275e17-22.

3. SANPEI S, ENDO T, SHIMOOKA S. Caries risk factors in children under treatment with sectional brackets. Angle Orthod 2010;80:509-14.

4. LOVROV S, HERTRICH K, HIRSCHFELDER U. Enamel demineralization during fixed orthodontic treatment - incidence and correlation to various oral-hygiene parameters. J Orofac Orthop 2007;68:353-63.

5. FINK DF, SMITH RJ. The duration of orthodontic treatment. American Journal of Orthodontics and Dentofacial Orthopedics: official publication of the American Association of Orthodontists, its constituent societies, and the American Board of Orthodontics 1992;102:45-51.

6. LEVIN L, EINY S, ZIGDON H, AIZENBUD D, MACHTEI EE. Guidelines for periodontal care and followup during orthodontic treatment in adolescents and young adults. J Appl Oral Sci2012;20:399-403.

7. ZIMMER BW, ROTTWINKEL Y. Assessing patient-specific decalcification risk in fixed orthodontic treatment and its impact on prophylactic procedures. Am J Orthod Dentofacial Orthop 2004;126:318-24.

8. FRANCO e FRANCO TC, AMOROSO P, MARIN JM, de AVILA FA. Detection of Streptococcus mutans and Streptococcus sobrinus in dental plaque samples from Brazilian preschool children by polymerase chain reaction. Braz Dent J 2007;18:329-33.

9. PANDIS N, PAPAIOANNOU W, KONTOU E, NAKOU M, MAKOU M, ELIADES T. Salivary Streptococcus mutans levels in patients with conventional and self-ligating brackets. Eur J Orthod 2010;32:94-9.

10. NURELHUDA NM, Al-HARONI M, TROVIK TA, BAKKEN V. Caries experience and quantification of Streptococcus mutans and Streptococcus sobrinus in saliva of Sudanese schoolchildren. Caries Res 2010;44:402-7.

11. HIROSE H, HIROSE K, ISOGAI E, MIURA H, UEDA I. Close association between Streptococcus sobrinus in the saliva of young children and smooth-surface caries increment. Caries Res 1993;27:292-7.

12. NAVAZESH M. Methods for collecting saliva. Ann N Y Acad Sci 1993;694:72-7.

13. GREENE JC, VERMILLION JR. The simplified oral hygiene index. J Am Dent Assoc 1964;68:7-13.

14. World Health Organization. Oral health surveys: basic methods. $5^{\text {th }}$ edn. Geneva: WHO Press, 2013.

15. ULUDAMAR A, EVREN BA, ISERI U, OZKAN YK. Oral health status and treatment requirements of different residential homes in Istanbul: a comparative study. Arch Gerontol Geriatr 2011;53:e67-74.

16. WATANABE K, FROMMEL TO. Detection of Porphyromonas gingivalis in oral plaque samples by use of the polymerase chain reaction. J Dent Res 1993;72:1040-4.

17. JURELA A, REPIC D, PEJDA S, JURIC H, VIDAKOVIC R, MATIC I, et al. The effect of two different bracket types on the salivary levels of $S$. mutans and $S$. sobrinus in the early phase of orthodontic treatment. Angle Orthod 2013;83:140-5.

18. SMIECH-SLOMKOWSKA G, JABLONSKA-ZROBEK $\mathrm{J}$. The effect of oral health education on dental plaque development and the level of caries-related Streptococcus mutans and Lactobacillus spp. Eur J Orthod 2007;29:157-60.

19. Al MAAITAH EF, ADEYEMI AA, HIGHAM SM, PENDER N, HARRISON JE. Factors affecting demineralization during orthodontic treatment: a post-hoc analysis of RCT recruits. Am J Orthod Dentofacial Orthop 2011;139:181-91.

20. Al MULLA AH, KHARSA SA, KJELLBERG $\mathrm{H}$, BIRKHED D. Caries risk profiles in orthodontic patients at follow-up using cariogram. Angle Orthod 2009;79:323-30.

21. SCHIFFNER U, HOFFMANN T, KERSCHBAUM T, MICHEELIS W. Oral health in German children, adolescents, adults and senior citizens in 2005. Community Dent Health 2009;26:18-22.

22. PELTOLA JS, VENTA I, HAAHTELA S, LAKOMA A, YLIPAAVALNIEMI P, TURTOLA L. Dental and oral radiographic findings in first-year university students in 1982 and 2002 in Helsinki, Finland. Acta Odontol Scand 2006;64:42-6.

23. GRAY D, McINTYRE G. Does oral health promotion influence the oral hygiene and gingival health of patients undergoing fixed appliance orthodontic treatment? A systematic literature review. J Orthod 2008;35:262-9.

24. CHANG HS, WALSH LJ, FREER TJ. The effect of orthodontic treatment on salivary flow, $\mathrm{pH}$, buffer capacity, and levels of mutans streptococci and lactobacilli. Aust Orthod J 1999;15:229-34.

25. ULUKAPI H, KORAY F, EFES B. Monitoring the caries risk of orthodontic patients. Quintessence Int 1997;28:27-9.

26. AHN SJ, LIM BS, LEE SJ. Prevalence of cariogenic streptococci on incisor brackets detected by polymerase chain reaction. Am J Orthod Dentofacial Orthop 2007;131:736-41.

27. SEKI M, YAMASHITA Y, SHIBATA Y, TORIGOE $H$, TSUDA H, MAENO M. Effect of mixed mutans streptococci colonization on caries development. Oral Microbiol Immunol 2006;21:47-52.

28. ORTENDAHL T, THILANDER B, SVANBERG M. Mutans streptococci and incipient caries adjacent to glass ionomer cement or resin-based composite in orthodontics. Am J Orthod Dentofacial Orthop 1997;112:271-4. 
Sažetak

\section{PROMJENE U ZDRAVLJU USNE ŠUPLJINE TIJEKOM RANE FAZE ORTODONTSKE TERAPIJE}

\section{K. Sudarević, A. Jurela, D. Repić, D. Jokic, I. Medvedec, H. Jurić i S. Pejda}

Svrha istraživanja bila je utvrditi utjecaj fiksnih ortodontskih naprava na broj kariogenih bakterija Streptococcus (S.) mutans i S. sobrinus u ortodontskih pacijenata s obzirom na njihov kariogeni status (indeks DMFT) tijekom prvih dvanaest tjedana ortodontske terapije. U istraživanju je sudjelovalo 22 ispitanika koji su zadovoljili kriterije za uključenje: uredno opće i parodontno zdravlje, izbjegavanje antiseptika za ispiranje usne šupljine i antibiotika u prethodna tri mjeseca. Sva klinička mjerenja napravljena su prije (T1) i 12 tjedana nakon (T2) postavljanja fiksne ortodontske naprave sljedećim redoslijedom: 1) količina stimulirane sline (SS), 2) Simplified Oral Hygiene Index (OHI-S) i 3) DMFT. Reakcija lančane polimeraze (PCR) je korištena za otkrivanje prisutnosti S. mutans i S. sobrinus prilikom T1 i T2. T-test je pokazao značajan porast indeksa DMFT i SS između T1 i T2. Rezultati također pokazuju značajno poboljšanje indeksa OHI-S. Koristeći PCR metodu S. mutans je otkriven kod dvoje ispitanika na T1. Nakon 12 tjedana fiksne ortodontske terapije došlo je do porasta broja ispitanika kod kojih je otkriven $S$. mutans, ali porast nije bio statistički značajan. Istom metodom $S$. sobrinus je otkriven tek u dvoje ispitanika na T2. U zaključku, tijekom prvih 12 tjedana fiksne ortodontske terapije nije došlo do statistički zančajne promjene u kariogenoj mikroflori. Primjena individualnih edukativnih i preventivnih mjera oralne higijene može spriječiti nastanak štetnih nuspojava tijekom fiksne ortodontske terapije.

Ključne riječi: Zubna caklina; Zubni karijes; Indeks DMF; S. mutans; S. sobrinus; Ortodontske naprave 